\title{
Camel milk production in northern Kenya
}

\author{
S. P. Simpkin
}

Department of Agriculture, The University, Newcastle-upon-Tyne NE1 7RU

\section{Introduction}

There are over 600000 camels (Camelus dromedarius) in Kenya, the ninth largest population in the world. They are managed primarily for milk production in the arid or semi-arid regions but they are also important for meat and transport. Camels are essential to the subsistence of a large number of people. The majority of camels are kept by nomadic pastoralists under an extensive management system, with little veterinary care, and no supplementary feeding. Small numbers of farmers have incorporated camels on to commercial beef cattle ranches, but only to control bush encroachment and supply milk to the employees (Evans and Powys, 1979). Camels are well adapted to the arid conditions and cause little damage to the environment.

This initial research into the constraints to camel production was carried out under UNESCO's Integrated Project in Arid Lands. The FARM-Africa Camel Improvement Project is putting some of these research results into practice by promoting better camel husbandry amongst farmers in the dry regions of Kenya.

\section{Material and methods}

Data from two herds of 60 camels were collected over a period of 3 years. One herd received a regular veterinary input and was called the TREATMENT herd; the other herd only received traditional remedies and acted as the CONTROL herd. Both herds were managed in the traditional extensive management system adopted by Rendille camel pastoralists. The forage availability and quality, grazing time, milking frequency, interval between watering, and breeding control were the same for both herds.

Camels were milked by hand both morning and evening and the volume measured and recorded on the same day each week. Total yields were calculated from these data. Butterfat content of the milk was measured, on a monthly basis, using the Gerber method.
Health status, body condition, birth weight, growth rate, mortality, and calving interval were monitored regularly.

Data from camel herds on two ranches were collected for comparison. Ranch herds were under better management with less competition for forage.

The veterinary package included regular application of acaracides and anthelmintics; and treatment with antibiotics and trypanocidal drugs as required. Traditional therapies included branding and use of plant extracts including tobacco.

\section{Results}

The variations in milk yield and composition across the four herds are shown in Table 1. Daily milk yields declined significantly as camels became dehydrated over the 11-day watering interval. Calving interval less than the 'average' 24 months significantly $(P=0.005)$ reduced the lactation length, and therefore the total yield $(P=0.05)$. Calf survival affected milk yield. Camels whose calves survived past weaning gave a total yield $2.9 \times$ greater than camels whose calves died before weaning.

Table 1 Milk yield of four camel herds in Kenya - adjusted to 365-day lactation

\begin{tabular}{|c|c|c|c|c|}
\hline & Control & Ranch 1 & Treatment & Ranch 2 \\
\hline $\begin{array}{l}\text { Mean daily } \\
\text { yield (kg) } \\
\text { Total yield (kg) }\end{array}$ & $\begin{array}{c}2 \cdot 19^{a} \pm 1 \cdot 2 \\
799\end{array}$ & $\begin{array}{c}2.83^{b} \pm 0.5 \\
1033\end{array}$ & $\begin{array}{c}3 \cdot 12^{b} \pm 1 \cdot 2 \\
1039\end{array}$ & $\begin{array}{c}5 \cdot 33^{c} \pm 1.5 \\
1945\end{array}$ \\
\hline $\begin{array}{l}\text { Mean butterfat } \\
\text { content }(\mathrm{g} / \mathrm{kg}) \\
\text { Total solids }\end{array}$ & $40 \cdot 6^{b} \pm 12 \cdot 2$ & $40 \cdot 5^{b} \pm 13.7$ & $34.7^{\complement} \pm 12 \cdot 8$ & NR \\
\hline$(\mathrm{g} / \mathrm{kg})$ & $123 \cdot 1$ & NR & $120 \cdot 2$ & NR \\
\hline
\end{tabular}

$a, b, c$, Superscripts denote significant differences: $a b=$ $P<0.05 ;$ bc $=P<0.005$.

NR = not recorded. 


\section{Conclusions}

Present levels of camel production fall well below potential. Factors that affect milk yields include: nutrition, health status, breed, calf survival, calving interval, milking frequency, interval between watering and parity.

Improved health status of the camel, through the use of veterinary drugs, improved calf survival and increased milk production, despite calving intervals being reduced. The use of veterinary drugs to increase camel productivity was cost effective. Simple improvements in herd management could substantially increase camel productivity in Kenya.

\section{References}

Evans, J. O. and Powys, J. G. 1979. Camel husbandry to increase the productivity of ranchland. In Camels. Provisional Report, International Foundation for Science, Stockholm, no. 6, pp. 241-250. 